\title{
Molecular Detection and Pathogenic Capability of Agrobacterium tumefaciens Isolates from Olive
}

\author{
Nagia M. Jadalla $^{1}$, Said I. Behiry ${ }^{2}$ and Mohamed A.M. Adam ${ }^{1}$
}

\begin{abstract}
Crown gall, caused by Agrobacterium tumefaciens, first reported on olive in Libya. A partial 16SrRNA gene sequence confirmed the identity of the $A$. tumefaciens bacterial isolates. The Ti-plasmid (induce tumors formation) is the real reason of their pathogenicity. Meanwhile, the prerequisite for the control of $A$. tumefaciens is to have a rapid and reliable detection method of pathogenic isolates in order to select healthy plants therefore, we detected two plasmidic genes, virD2 gene of the virulence (vir) region (amplified by virD2A/C and virD2A/E primers), and T-DNA (on tms gene). The PCR amplified bands analysis had a correspondence to the pathogenicity assay (carrot tumorgenicity) and the biochemical determents' of the isolates genus.
\end{abstract}

Key words: Agrobacterium tumefaciens; PCR; Tiplasmid; virD2; pathogenicity

\section{INTRODUCTION}

Agrobacterium tumefaciens is the causal agent of crown gall disease; the common neoplastic disease of dicot plants, including many woody shrubs and various herbaceous plants (DeCleene et al., 1976; Young et al., 2003; Rhouma et al., 2006; Younis et al., 2016). Knowledge of the ecology of Agrobacterium spp.-in soil and on plants- is limited, but such information is required to find better methods of managing crown gall disease. Tumor inducing assay relayed on isolation of pathogen on semi-selective media and performing the pathogenicity test (Moore et al 2001). Although time consuming and laborious, pathogenicity assay is the only reliable method for determining tumorgenicity of bacteria associated with grapevine crown gall. Agrobacterium strains may inhabit nursery soils for years before causing disease (Haas et al., 1995). Therefore, the pathogen can reside undetected in soils of locations where nurseries will be established. Thus, it is important to develop sensitive and reliable tools to detect A. tumefaciens in soils and plant material and to distinguish disease-producing strains from nonpathogenic strains (Kuzmanović et al., 2016). Since a virulence assay for Agrobacterium typically takes 3-4 weeks, several other methods have been developed, including the introduction of the polymerase chain reaction (PCR) in plant pathology (Burr et al., 1990) which, opened up new possibilities for rapid detection and identification of Agrobacterium in agriculturally important plants. First studies were started in the early 90s (Dong et al., 1992; Schulz et al., 1993). Pathogenic tumor-inducing isolates of Agrobacterium had a common feature which could permit their identity through DNA analysis: they contain the tumor-inducing (Ti) plasmid (Wang et al., 1990 ; Gelvin, 2017). Virulence depends upon two regions of the Ti plasmid: the transferred DNA (T-DNA) and the virulence (vir) genes (Zhang et al., 2017 ; Duan et al., 2018). Primers were designed to detect T-DNA and the vir region (Ponsonnet and Nesme, 1994; Haas et al., 1995; Sawada et al., 1995; Pulawska and Sobiczewski, 2005; Bini et al., 2008). The universal primers virD2A/C and virD2A/E were used to amplify the highly conserved DNA sequences in the virD2 gene of the vir region on the Ti plasmid. These results are supporting to identify of these isolates as A. tumefaciens (Eastwell et al., 1995; Szegedi and Bottka, 2002; Tolba and Soliman, 2014). Here, the goal of this study was to use a sensitive, specific and more rapid PCR-based method for detecting pathogenic A. tumefaciens in plant. Such a method is essential for early detection for nursery production of stone fruit trees and other plants susceptible to Agrobacterium crown gall disease.

\section{MATERIALS AND METHODS}

\section{Bacterial isolation and culture media}

Isolation trials were carried out from infected olive seedlings showing roots tumors, crown galls with well developed symptoms, collected from Benghazi region, Libya during 2017.The bacteria were isolated from symptomatic materials and streaked on glycerol nutrient agar according to described method of Moore et al. (2001) - After $48 \mathrm{~h}$ of incubation at $28^{\circ} \mathrm{C}$ the colonies were observed, isolated and kept purified on $2 \%$ glycerol nutrient agar slants for later use. In addition we used the strain C58 (kindly provided from Plant Pathology Department, Faculty of Agriculture, Alexandria University) as a reference in this study.

\section{Phenotypic identification}

The morphology of the bacterial isolates was examined by light microscopy. The physiological and

\footnotetext{
${ }^{1}$ Plant protection Department, Faculty of Agriculture -Omar Al-mukhtar University. Elbida-Libya

${ }^{2}$ Agricultural Botany Department, Faculty of Agriculture Saba Basha, Alexandria University, Alexandria, Egypt

Received September 06, 2018, Accepted September 30, 2018
} 
biochemical characteristics were carried out according to protocols described by Jones and Geider (2001).

\section{Detection of tumor-inducing isolates in carrot slices}

Tumorgenicity of the selected isolates was tested on the carrot slices (Daucus carota) according to Burr and Katz (1983).

\section{DNA extraction}

The DNA of all bacterial isolates was extracted as a method described by Ausubel et al., (1995).

\section{PCR analyses by 16Sr RNA, virD2 and tms2 genes}

A partial portion of $16 \mathrm{~S}$ rRNA gene was amplified for all bacterial isolates using universal primers $\mathrm{P} 0$ and $\mathrm{P} 6$, for detecting the virD2 gene (virD2A/C and virD2A/E) and for amplifying iaaH (tms2) gene (tms2Fl/tms2B) (Table 2). PCR amplifications accomplished with $2 \mu \mathrm{L}$ of template DNA, $12.5 \mu \mathrm{L}$ of master mix (iNtron, Korea), $0.5 \mu \mathrm{L}$ of $10 \mathrm{pmol}$ of each primer as what gene detects and molecular grade water to be added up to $25 \mu \mathrm{L}$. The amplification was performed as one cycle at $95^{\circ} \mathrm{C}$ for 5 min followed by 34 cycles each with $45 \mathrm{~s}$ at $95^{\circ} \mathrm{C}$ for denaturation, $1 \mathrm{~min}$ at $50^{\circ} \mathrm{C}$ annealing for all genes, and $1 \mathrm{~min}$ at $72^{\circ} \mathrm{C}$ for elongation and for final extension $7 \mathrm{~min}$ at $72^{\circ} \mathrm{C}$. The PCR products were suggested to run in $1 \%$ agarose gel in Tris Acetate EDTA (TAE) buffer, stained with Ethidium bromide and visualized on transilluminator.

\section{Sequencing of 16S rRNA gene and alignment}

The purified fragments of partial 16S rRNA gene were sequenced by Macrogen inc., Soul, Korea. To identify the bacterial isolates, the achieved sequences were blasted in GenBank database at the National
Center for Biotechnology Information (NCBI) site (http://www.ncbi. nlm.nih.gov), nucleotide sequences were submitted to the GenBank submission portal and assigned to have accession numbers. Phylogenetic relationships were evaluated using the $16 \mathrm{~S}$ rDNA sequences of isolates identified from olive seedlings, and other sequences from GenBank reference using the maximum parsimony method of MEGA 6. The bootstrap consensus tree was inferred from 1000 replicates.

\section{RESULTS AND DISCUSSION}

\section{Isolation and initial characterization}

Four bacterial isolates were isolated from infected olive roots tumors as stated in materials and methods compared with the reference isolate C58. Distinct colonies that had typical morphological and biochemical characteristics of Agrobacterium tumefaciens as recorded by Schroth et al (1965); Moore et al. (2001); Adenemo and Onilude (2014) and Ali et al. (2016) were purified and listed in (Table 1).

\section{Pathogenicity of Agrobacterium isolates}

On the basis of carrot tumorgenicity test carried out on carrot slices, all the tested Agrobacterium isolates were characterized as tumor-inducing (Fig.1). In other speech, as Tolba and Soliman, (2014) declared that the tumorgenicity should be the clear evidence on the belonging of the isolate to the genus Agrobacterium. Therefore, pathogenicity test was conducted at the outset of the study in order to selecting the tumorigenic isolates.

Table 1. Morphological traits, physiological, biochemical reactions, isolate code and accession numbers of bacterial isolates obtained from infected samples, compared with the reference strain C58 of Agrobacterium tumefaciens

\section{Characteristic}

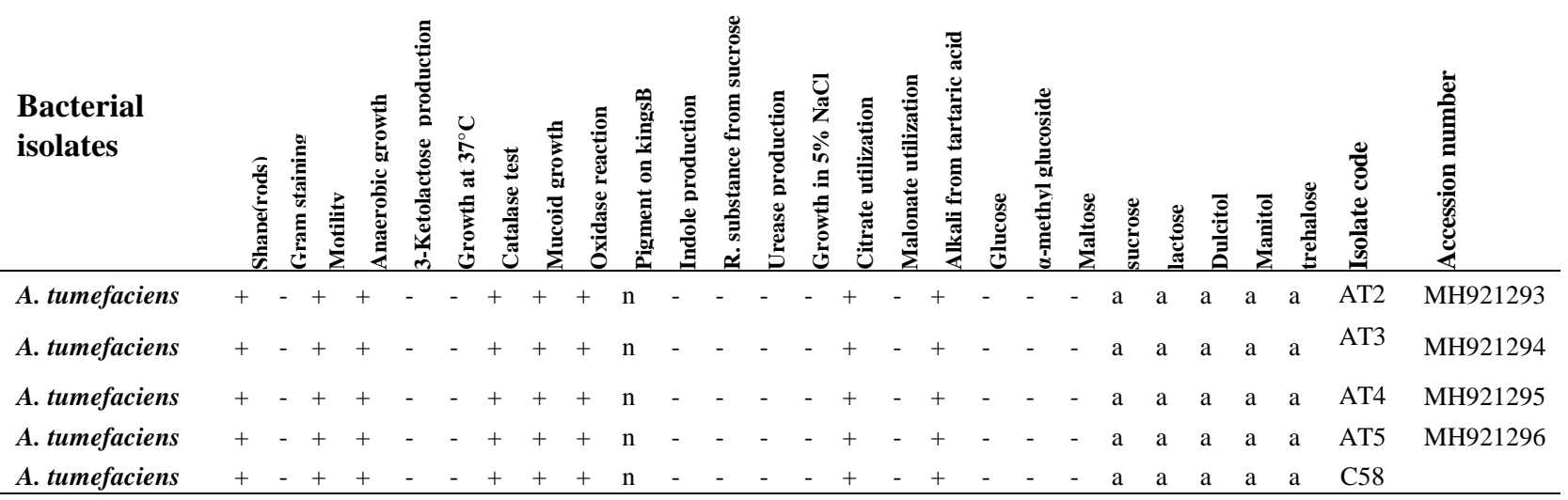

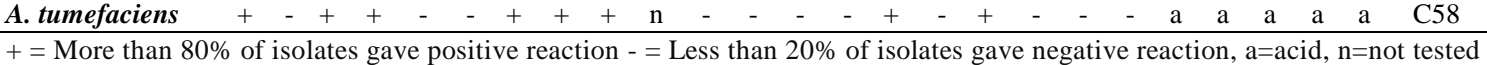




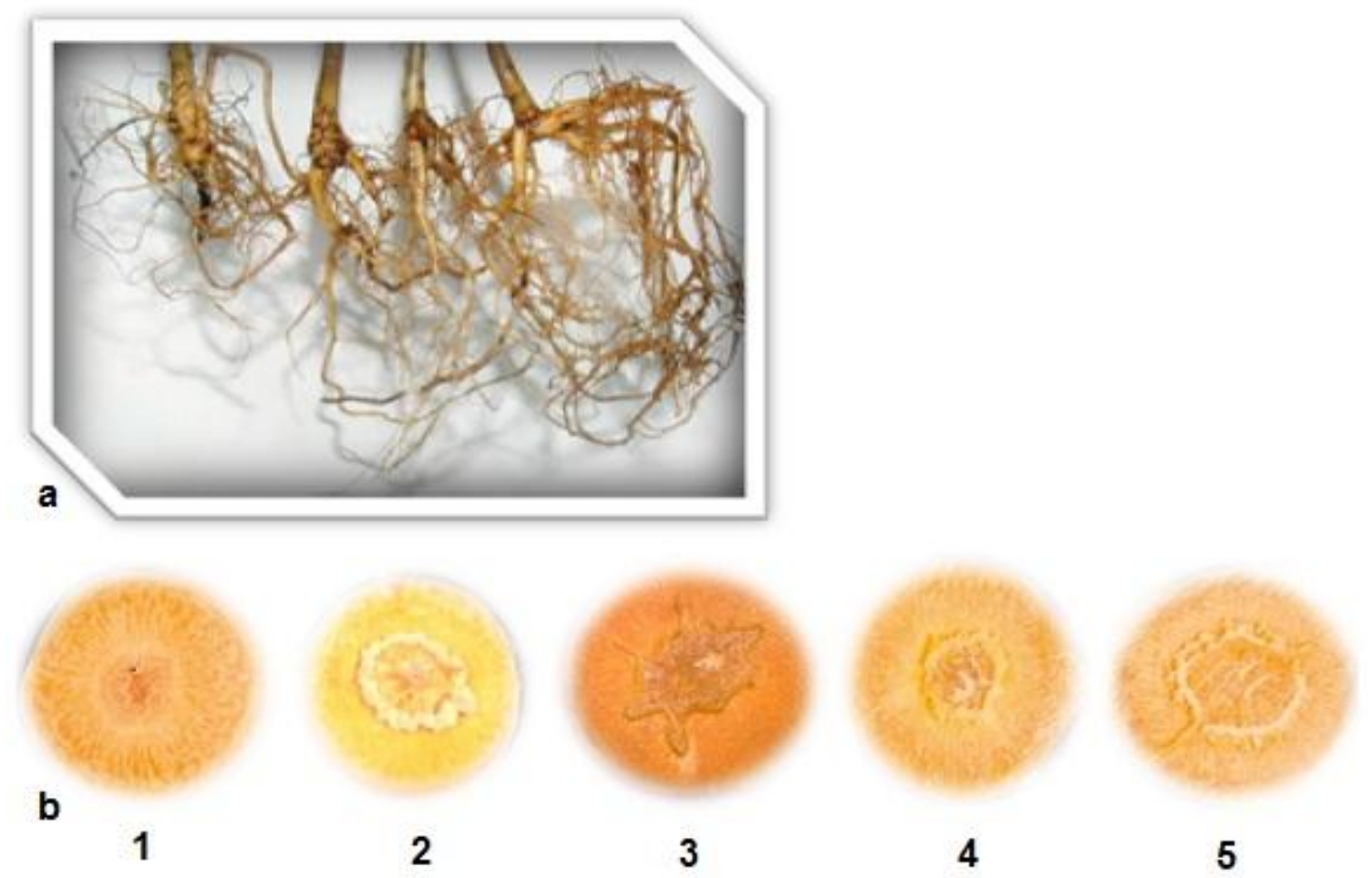

Fig. 1.a) the naturally infected olive seedlings with Agrobacterium showing galls on twigs and roots and b) 1; control and 2, 3, 4, 5; Agrobacterium isolates exhibited white small tumors induced on the surface of carrot discs

\section{Multigenic identification}

\section{Vir and tms region of the Ti-plasmid}

The PCR result of the virD2 region in all tested Agrobacterium isolates and the reference strain C58 also were positive. In Fig. 2, the primer pairs virD2A/C and virD2A/E amplified specific fragments of 224 and $338 \mathrm{bp}$ respectively. These results were in the same way of further phenotypic and tumorgenicity tests identity of the present isolates as A. tumefaciens, which was in agreement of previous reports (Saiki et al., 1988; Bini et al., 2008; Tolba and Soliman, 2014; Kuzmanović et al., 2016). Interestingly, all isolates gave positive amplification signal with $\operatorname{virD} 2 \mathrm{~A} / \mathrm{C}$ and $\operatorname{virD} 2 \mathrm{~A} / \mathrm{E}$ primer pairs were the same as that giving strong amplification signal with primer pair tms $2 \mathrm{Fl} / \mathrm{tms} 2 \mathrm{~B}$. All primer pairs studied provided reliable identification of all tumorigenic isolates of A.tumefaciens, as in line with Kuzmanović et al., 2016. For a practical point of view, PCR detection of sequences in Ti-plasmid is sufficient for diagnosis of Agrobacterium isolated but not for further species identification or differentiation, therefor the 16SrRNA gene sequencing were used.

\section{The bacterial 16S rRNA partial gene identification}

The region of the $16 \mathrm{~S}$ rRNA gene (1550bp) was amplified for all the bacteria isolates utilizing the universal primers P0 and P6. The sequences obtained from Macrogen, inc, Korea, used in the BLAST ncbi tool and revealed that, all isolates were identical to those of Agrobacterium tumefaciens and showed homology with Agrobacterium tumefaciens GenBank isolates reached to $99 \%$ or $100 \%$. The nucleotide sequences were GenBank accessioned with numbers illustrated in Table 2.

\section{Phylogenetic analysis}

The phylogenetic tree confirmed the sequence comparison analysis since the four 16S- rRNA sequences of $A$. tumefaciens clustered in different phylogenetic branch each other's (Fig.3). In any case, many efforts could be forward towards the development of more specific and sensitive real-time PCR assay as more sufficient detectable tool than the conventional PCR and of course more primers are needed to deep characterize agrobacteria strains. 


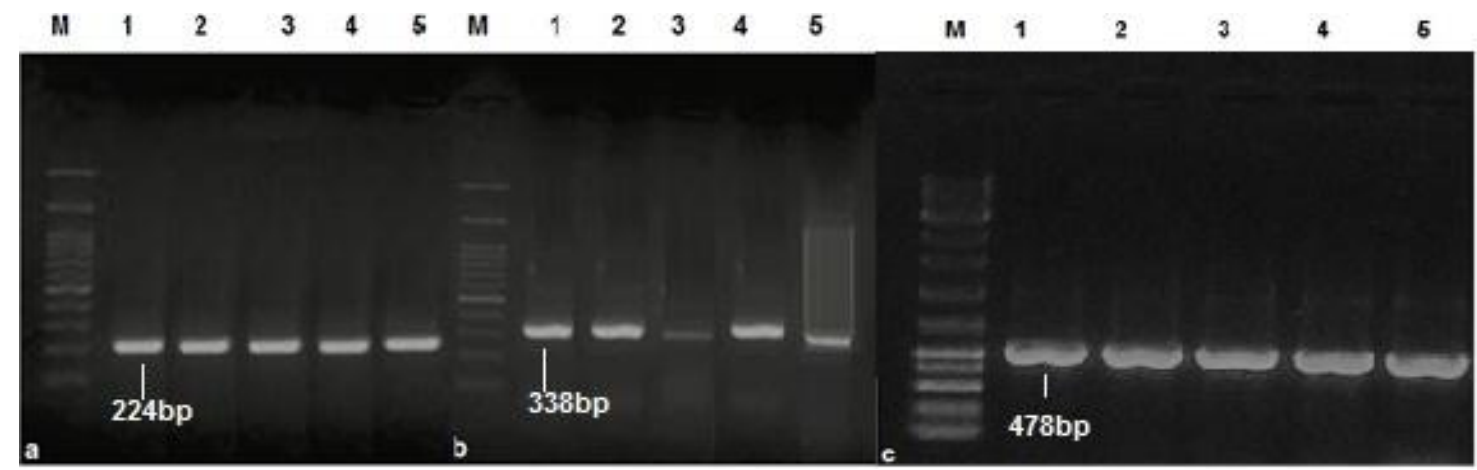

Fig.2. Specific amplified pattern on agarose gels, a) 224bp amplicon amplified by primer pair virD2A/C ,in, b) 338 bp amplicon amplified by virD2A/E, in, c) 478bp amplicon amplified by tms2F1/B detecting tms 2 gene and M; 100bp DNA Ladder

Table 2. Primers used in this study

\begin{tabular}{lcl}
\hline Primer & Target gene & \multicolumn{1}{c}{ Sequence 5` to 3` } \\
\hline virD2A & & ATGCCCGATCGAGCTCAAGT \\
virD2C & virD2 & TCGTCTGGCTGACTTCGTCATAA \\
virD2E & & CCTGACCCAAACATCTCGGCTGCCCA \\
tms2F1 & TTTCAGCTGCTAGGGCCACATCAG \\
tms2B & $a a H(t m s 2)$ & GGAGCACTGCCGGGTGCCTCGGGA \\
P0 & & GAAGAGTTTGATCCTGGCTCAG \\
P6 & 16S rRNA & CTACGGCTACCTTGTTACGA \\
\hline
\end{tabular}

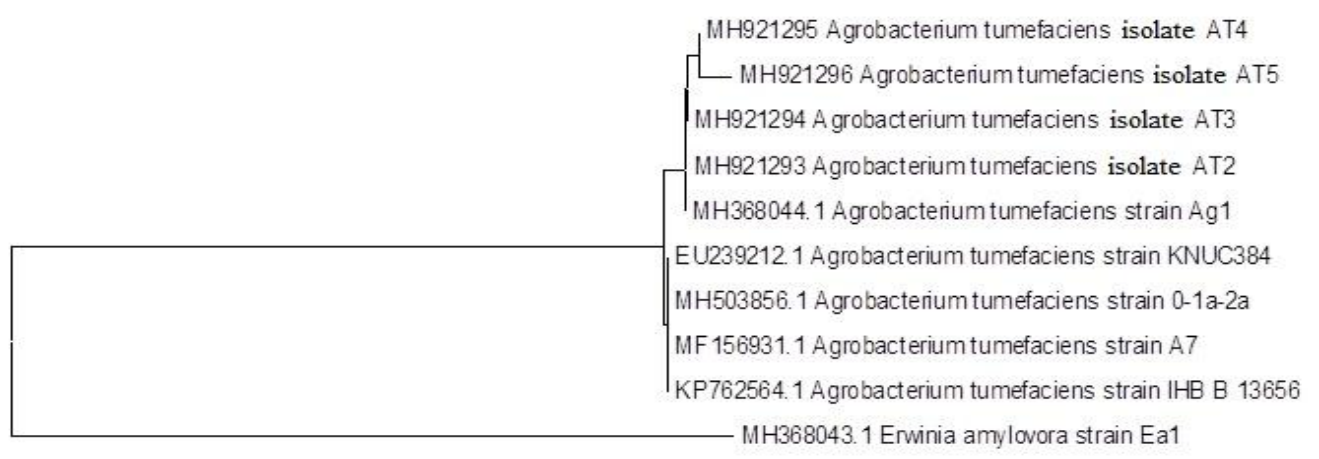

Fig.3. A rooted molecular phylogenetic tree using Maximum Likelihood method. Bootstrap values above 500 are shown. Five closely related nucleotide sequences from the $A$. tumefaciens isolates. The sequences of four $A$. tumefaciens isolates having code (AT2,AT3,AT4 and AT5) from olive obtained in this work are in distinct cluster. On the left of the branch the GenBank accession number of the isolates employed. The bacterial strain Erwinia amylovora was used as out group to root the tree.

\section{REFERENCES}

Adenemo, S. M., and A. A. Onilude. 2014. Molecular identification of Lactobacillus plantarum isolated from fermenting cereals. International Journal for Biotechnology and Molecular Biology Research.5(6): 5967.
Ali, N., A. Zada, M. Ali and Z. Hussain. 2016. Isolation and identification of Agrobacterium tumefaciens from the galls of peach tree. Journal of Rural Development and Agriculture. 1(1): 39-48. Retrieved from http://journal.aiou.edu.pk/journal2/index.php/JRDA/articl e/view/24 
Ausubel, F.M., R. Brent, R.E. Kingston, D.D. Moore, J.G. Seidman, J.A. Smith and K. Struhl. 1995. Preparation of Genomic DNA from Bacteria. In: Current Protocols in Molecular Biology, Ausubel, F.A., R.E. Brent, D.D. Kingston, J.G. Moore and J.A. Seidman (Eds.). John Wiley and Sons. New York.

Bini, F., A. Kuczmog, P. Putnoky, L. Otten, C. Bazzi and T. J. Burr. 2008. Novel pathogen-specific primers for the detection of Agrobacterium vitis and Agrobacterium tumefaciens. Vitis. 47:181-189.

Burr, T.J. and B.H. Katz. 1983. Isolation of Agrobacterium tumefaciens biovar 3 from grapevine galls and sap, and from vineyard soil. Phytopathol. 73: 163-165.

DeCleene, M. and J. DeLey. 1976. The host range of crown gall. Bot. Rev. 42:389-466.

Dong, L. C., C. W. Sun, K. L. Thies, D. S. Luthe and C. H. Graves. 1992. Use of polymerase chain reaction to detect pathogenic strains of Agrobacterium. Phytopathology. 82: 434-439.

Duan, K., C. Willig, J.R. de Tar . 2018. Transcriptomic analysis of Arabidopsis seedlings in response to Agrobacterium-mediated transformation process. Mol Plant Microbe Interact 31:445-459

Eastwell, K.C., L.G. Willis and T.D. Cavileer. 1995.A rapid and sensitive method to detect Agrobacterium vitis in grapevine cuttings using the polymerase chain reaction. Plant Disease. 79: 822-827.

Gelvin, S.B. 2017. Integration of Agrobacterium T-DNA into the plant genome. Annu Rev Genet 51:195-217

Haas, J.H., L.W. Moore, W. Ream, and S. Manulis. 1995. Universal PCR primers for detection of phytopathogenic Agrobacterium strains. Appl. Environ. Microbiol. 61: 2879-2884.

Jones, A.L. and K. Geider. 2001. Gram-Negative Bacteria, In: Laboratory Guide for Identification of Plant Pathogenic Bacteria, Schaad, N.W., J.B. Jones and W. Chun (Eds.). 3rd Edn., APS Press, St Paul. MN. USA.

Kuzmanović, N. , E. Biondi, M. Ivanović, A. Prokić, N. Zlatković, A. Bertaccini and A. Obradović. 2016. Evaluation of different PCR primers for identification of tumorigenic bacteria associated with grapevine crown gall. Journal of Plant Pathology. 98. 2 : 311-319

Moore, L.W., H. Bouzar and T.J. Burr. 2001.Agrobacterium. In Schaad, N.W.; Jones, J.B.; Chun, W. eds, Laboratory Guide for Identification of Plant Pathogenic Bacteria. American Phytopathological Society Press, St. Paul, Minnesota. pp:17-33.

Ponsonnet, C. and X. Nesme. 1994. Identification of Agrobacterium strains by PCR RFLP analysis of pTi and chromosomal regions. Arch. Microbiol. 161: 300- 309.
Pulawska, J. and P. Sobiczewski. 2005. Development of a semi-nested PCR based method for sensitive detection of tumorigenic Agrobacterium in soil. J. Appl. Microbiol., 98: 710-721.

Rhouma, A., A. Boubaker, X. Nesme and Y. Dessaux. 2006. Plasmid and chromosomal diversity of a Tunisian collection of Agrobacterium tumefaciens strains. Tunisian J. Plant Prot. 1: 73-84.

Saiki, R. K., D. H. Gelfand, S. Stoffel, S. J. Scharf, R. Higuchi, G. T. Horn, K. B. Mullis and H. A. Erlich. 1988. Primer-directed enzymatic amplification of DNA with a thermostable DNA polymerase. Science. 239:487-491.

Sawada, H., H. Ieki, and I. Matsuda. 1995. PCR detection of $\mathrm{Ti}$ and Ri plasmids from phytopathogenic Agrobacterium strains. Appl Environ Microbiol. 61: 828-831.

Schroth, M.N., J.P. Thompson, and D.C. Hildebrand. 1965. Isolation of Agrobacterium tumefaciens - A. radiobacter group from the soil. Phytopathology. 55:645-647.

Schulz, T.F., D. Lorenz, K.W. Eichhorn and L. Otten. 1993. Amplification of different marker sequences for identification of Agrobacterium vitis strains. Vitis. 32: 179-182.

Szegedi, E. and S. Bottka. 2002. Detection of Agrobacterium vitis by polymerase chain reaction in grapevine bleeding sap after isolation on a semi selective medium. Vitis. 41: $37-42$.

Tolba, I. H. and M. A. Soliman. 2014. Phenotypic and molecular characterization of tumorigenic Agrobacterium tumefaciens strains isolated from rose plant in Egypt. Middle East Journal of Agriculture Research. 3(4): 10021014

Wang, K., A. Herrera-Estrella, and M. Van Montagu.1990. Overexpression of virD1 and virD2 genes in Agrobacterium tumefaciens enhances T-complex formation and plant transformation. J. Bacteriol. 172:4432-4440.

Young, J. M., L. D. Kuykendall, E. Martı'nez-Romero, A. Kerr, and H. Sawada. 2003. Classification and nomenclature of Agrobacterium and Rhizobium - a reply to Farrand et al. (2003). International Journal of Systematic and Evolutionary Microbiology. 53: 16891695.

Younis, A. M., A. A. Shoeib, M. A. Elsaedy and K.A. Osman. 2016. Efficacy of ozone and hydrogen peroxide on controlling crown gall bacterium and root knot nematode infected Guava plants in Egypt. Alex. J. Agric. Sci. 61(6):517-527

Zhang, X., G.P.H. van Heusden, P.J. Hooykaas. 2017. Virulence protein VirD5 of Agrobacterium tumefaciens binds to kinetochores in host cells via an interaction with Spt4. Proc Natl Acad Sci 114:1023810243 


\section{الملخص العربي \\ التوصيف الجزيئى والقدرة الامراضية لبكتيريا الأجروياكتيريم تيوميفاشنز المعزولة من شتلات الزيتون \\ نجية محمد جادالله ، سعيد ابراهيم عبداله بحيرى و محمد ادم}

على احداث العدوى والاصدابة بالتورمات، لذا فقد ركزت تلك

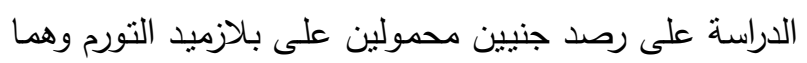

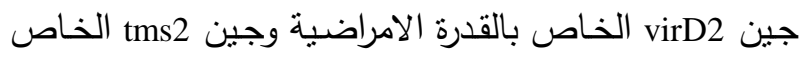
بتخليق الاوكسينات. وتبين من الدراسة وجود علاقة بين قدرة البكتيرات على الامراضية ووجود هذه الجينات المحمولة على لهى

.Ti-plasmid
تم التعرف على البكتيـرات المعزولـة مـن عـرض التـدرن التـاجى فـى شــتلات الزيتــون بالثـــل المظهــرى والطــرق

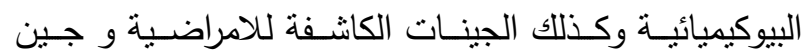

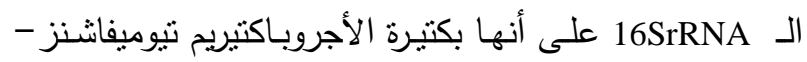
لأول مـرة يـتم تسـجيلها على شـتلات الزيتـون فـى ليبيـا -

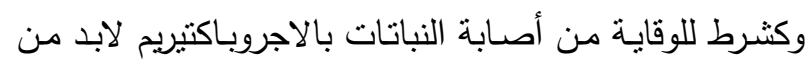
تحديث طريقة للكثف السريع عن البكتيرات التى لها القدرة 